Review

\title{
The hydrosoluble fiber Plantago ovata husk improves levodopa (with carbidopa) bioavailability after repeated administration
}

\author{
M. Jose Diez, Juan J. Garcia, Carlos Prieto, Nelida Fernandez*, Ana Sahagun, Matilde Sierra \\ Area de Farmacologia, Universidad de Leon, 24071, Leon, Spain
}

Received 19 November 2007; received in revised form 11 March 2008; accepted 18 March 2008

Available online 12 May 2008

\begin{abstract}
The influence of treatment duration ( 7 or 14 days) with Plantago ovata husk/levodopa/carbidopa in the bioavailability and other pharmacokinetic parameters of levodopa were evaluated in rabbits. Fiber was administered at two different doses, $100 \mathrm{and} 400 \mathrm{mg} / \mathrm{kg}$, and the dosage of levodopa/carbidopa was $20: 5 \mathrm{mg} / \mathrm{kg}$. These doses were administered once a day. When $100 \mathrm{mg} / \mathrm{kg}$ of fiber was administered, the mean AUC value obtained for levodopa increased $20.2 \%$ from day 1 to day 7 , and $27.2 \%$ from day 1 to day $14 ; C_{\max }$ was $8.6 \%$ higher on day 7 and $11.7 \%$ higher on day 14 . When administering $400 \mathrm{mg} / \mathrm{kg}$ of fiber, the increase in AUC values was $17.6 \%$ on day 7 and $24.9 \%$ on day 14 , and that of $C_{\max } 11.1 \%$ on day 7 and $11.3 \%$ on day 14 . The concentration determined immediately before drug administration $\left(C_{\text {min }}\right)$ increased progressively with the duration of treatment, and the highest increase (53.2\%) was observed on day $14 \mathrm{with} 100 \mathrm{mg} / \mathrm{kg}$ of fiber. There was also a delay in levodopa elimination (higher MRT and lower $\mathrm{Cl}$ ) in a fiber-dose dependent manner. In summary, we found that there was an improvement in the extent of levodopa absorbed with higher final concentrations and that levodopa elimination was slower with the administration of $P$. ovata husk.
\end{abstract}

(C) 2008 Elsevier B.V. All rights reserved.

Keywords: Levodopa bioavailability; Carbidopa; Plantago ovata husk; Pharmacokinetics; Rabbits

\section{Contents}

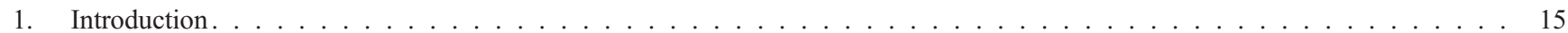

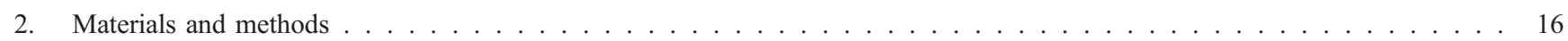

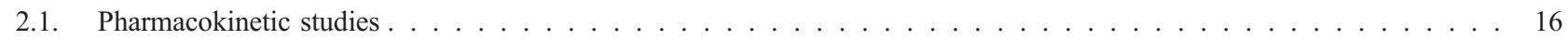

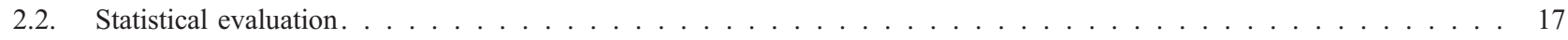

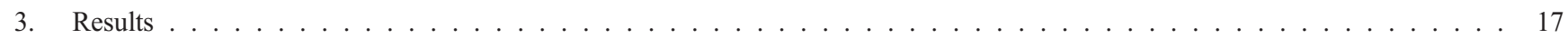

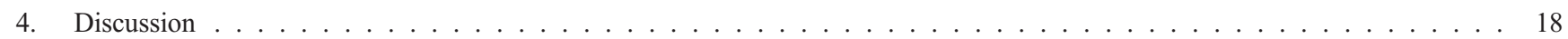

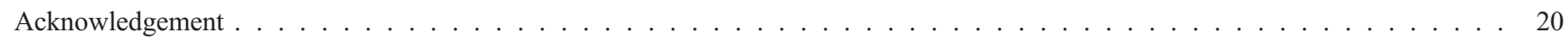

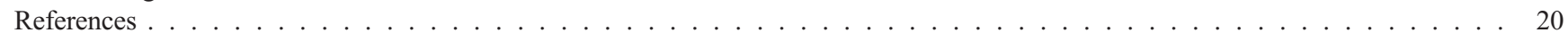

* Corresponding author. Tel.: +3498729 15 28; fax: +34 987291252.
E-mail address: nelida.fernandez@unileon.es (N. Fernandez).

0022-510X/\$ - see front matter (C) 2008 Elsevier B.V. All rights reserved. doi:10.1016/j.jns.2008.03.007

\section{Introduction}

A major problem with levodopa treatment are the fluctuations in clinical response experienced in patients with advanced Parkinson's disease. Some of these fluctuations (e.g. wearing-off, on-off) in motor performance are related to 
the peripheral pharmacokinetics of levodopa [1-5]. Pulsatile simulation of striatal dopamine receptors induces molecular and neurophysiological changes in striatal neurons that are associated with dyskinesias $[1,6]$.

As a result of rapid intestinal absorption and metabolic elimination, plasma levodopa concentrations can fluctuate widely [2]. Early in the course of illness, there is no clear-cut relationship between plasma levodopa profile and antiparkinsonian effect [3]. With the progression of the disease, a correlation between levodopa plasma concentration and clinical effect emerges [4]. In more advanced stages of Parkinson's disease the clinical response mirrors the rapid rise and fall in plasma levodopa concentrations after each dose (the "wearing-off" phenomena). At this point, even small changes in levodopa disposition can greatly affect the therapeutic response. The pharmacokinetic optimization of levodopa dosage becomes essential to obtain reproducible plasma profiles and matched therapeutic responses [7-9].

Gastrointestinal symptoms such as nausea, abdominal pain, and bloating are frequent complaints in patients with Parkinson's disease. It has been postulated that impaired gastrointestinal function may contribute to the development of motor fluctuations, such as delay on and no on, in patients with Parkinson's disease. Impaired gastrointestinal function and symptoms may be associated with the disease itself or may be secondary to levodopa treatment [10].

Fiber therapy could be employed to reduce the symptoms of gastrointestinal motility disorders, because it regulates stool transit in the small as well as in the large intestine. In previous studies, we found an improvement in some pharmacokinetic parameters of levodopa when administered with Plantago ovata husk alone or in the presence of carbidopa. We observed higher final concentrations of levodopa, a longer plasma half-life, and lower values of $C_{\max }[11,12]$. However, the AUC values diminished when levodopa/carbidopa were administered with fiber (possibly because fiber retains part of the carbidopa) although there was less of a decrease at higher fiber doses. This could indicate that $P$. ovata husk has a similar mechanism of action as carbidopa (inhibition of LAAD) and, would need a period of time to stabilize its action. The results could be different, therefore, if these drugs are administered for several days. The purpose of the present study is to establish the influence of $P$. ovata husk in the bioavailability and other pharmacokinetic parameters of levodopa when orally administered to rabbits with carbidopa and fiber for different periods of time (7 and 14 days). We also evaluate whether pharmacokinetic modifications are fiber-dose dependent.

\section{Materials and methods}

Twenty-four healthy New Zealand white rabbits weighing 2.84 to $3.31 \mathrm{~kg}$ were used. The animals were housed in individual metal cages, which allowed the isolation of faeces in a lower container to avoid coprophagia. The environmental conditions were: humidity $(55 \pm 10 \%)$, temperature $\left(19 \pm 2{ }^{\circ} \mathrm{C}\right)$, and $12 \mathrm{~h}$ light $-12 \mathrm{~h}$ dark cycle. Rabbits were maintained under these conditions at least one week before the assay, with free access to water and standard laboratory chow.

The rabbits were randomly divided into four groups of 6 rabbits each. All the animals received $P$. ovata husk (Plantaben ${ }^{\circledR}$, Madaus, Barcelona, Spain) immediately before oral administration of $20: 5 \mathrm{mg} / \mathrm{kg}$ levodopa/carbidopa (Sinemet ${ }^{\circledR}$ ) once a day at the same hour in the morning. The different treatments were as follows:

- Group 1. - 20:5 mg/kg levodopa/carbidopa and P. ovata husk $(100 \mathrm{mg} / \mathrm{kg})$ for 7 days

- Group 2. - 20:5 mg/kg levodopa/carbidopa and P. ovata husk $(100 \mathrm{mg} / \mathrm{kg})$ for 14 days

- Group 3. - 20:5 mg/kg levodopa/carbidopa and P. ovata husk $(400 \mathrm{mg} / \mathrm{kg})$ for 7 days

- Group 4. - 20:5 mg/kg levodopa/carbidopa and P. ovata husk $(400 \mathrm{mg} / \mathrm{kg})$ for 14 days

The drugs were dispersed in water and administered by gastric intubation every morning at the same hour. A total of $50 \mathrm{ml}$ water was used for administration and cannula cleaning.

On the first (day 1) and the last day (day 7 or 14, respectively) of treatment, levodopa concentrations were determined at different sampling times after drug administration. To obtain blood samples, rabbits were anaesthetized with sodium pentobarbital (30 mg/kg body weight, i.v.) and the left carotid artery was cannulated with a silicone catheter (Silastic Medical-grade tubing, $1.02 \mathrm{~mm}$ inner diameter $\times 2.16 \mathrm{~mm}$ outer diameter). Drug administration was carried out after animals completely recovered from anaesthesia.

Blood samples $(3 \mathrm{ml})$ were obtained from the left carotid artery through the cannula into heparinized containers, immediately before drug administration and at 5, 10, 20, 30, 60, $90,120,180,240$ and 300 min after administration. In the animals of the first and third groups (7 days treatment), two blood samples were obtained immediately before $\left(C_{\min }\right)$ and at 20 min after drug administration $\left(C_{\max }\right)$ on days 3 and 5 from the marginal ear vein. In the second and fourth groups (14 days treatment) these samples were obtained on days 3 , 6, 9 and 11 .

Immediately after blood sample collection, the plasma was separated by centrifugation and stored at $-20{ }^{\circ} \mathrm{C}$ until analyzed. Levodopa extraction from plasma samples was carried out using a catecholamine kit (Chromsystems ${ }^{\circledR}$ ), and was quantified using HPLC with electrochemical detection. Neither heparin nor pentobarbital interfered with the assay.

\subsection{Pharmacokinetic studies}

Pharmacokinetic analysis was performed based on a noncompartmental description of the data. The maximum plasma levodopa concentration $\left(C_{\max }\right)$, and the time to reach maximum concentration $\left(t_{\max }\right)$, were read directly from the individual plasma concentration-time curves. 
The WinNonlin computer program and formulae described by Gibaldi and Perrier [13] were used to calculate the model-independent pharmacokinetic parameters. These parameters included the elimination rate constant $(\lambda)$, the area under the plasma concentration-time curve (AUC), clearance $(\mathrm{Cl} / \mathrm{F})$, the volume of area $\left(\mathrm{V}_{\mathrm{a}} / \mathrm{F}\right)$, the volume of distribution at steady state $\left(\mathrm{V}_{\mathrm{ss}} / \mathrm{F}\right)$, the half-life associated with $\lambda$ phase $\left(t_{1 / 2 \lambda}\right)$, the area under the first moment curve (AUMC), and the mean residence time (MRT).

The fraction of levodopa absorbed (F\%) was calculated by dividing the mean AUC by the value of the mean intravenous AUC obtained in a previous study [11] describing levodopa administration without fiber.

\subsection{Statistical evaluation}

All pharmacokinetic parameters were calculated for each animal and the data were presented as arithmetic mean \pm standard deviation (mean $\pm \mathrm{SD}$ ). Data were analysed using the Skewness test (to determine the normality) and the Cochran test (to determine the uniformity in the variance). When the data were normal and there was uniformity in the variance, a $t$-test was used to evaluate differences between days 1 and 7 and between days 1 and 14. When the data were not normal and/or there was not uniformity in the variance, Wilcoxon test was employed.

To evaluate differences in $C_{\min }$ and $C_{\max }$ a two-way analysis of variance (ANOVA) was carried out and the Duncan's test was used to determine differences between data sets. When the data were not normal or there was not uniformity in the variance, Kruskal-Wallis test was used. When the results were significant, Wilcoxon test was used to assess differences between data sets. $p \leq 0.05$ was used as the criteria for significance in all analyses.

\section{Results}

Fig. 1 shows the plots of mean plasma levodopa concentration as a function of time obtained on days 1 and 7 , and days 1 and 14, after oral administration of $20: 5 \mathrm{mg} / \mathrm{kg}$ levodopa/carbidopa and $P$. ovata husk $(100 \mathrm{mg} / \mathrm{kg})$. The plasma concentrations obtained with administration of $400 \mathrm{mg} / \mathrm{kg}$ of fiber are included in Fig. 2.

The non-compartmental pharmacokinetic parameters obtained in the four groups of animals are summarized in Tables 1 and 2. Table 3 shows the values of $C_{\min }$ and $C_{\max }$.

When levodopa and carbidopa were administered with $100 \mathrm{mg} / \mathrm{kg}$ of $P$. ovata husk, the mean AUC value increases significantly $(20.2 \%)$ from day 1 to day 7 and from day 1 to day $14(27.2 \%)$. The $C_{\max }$ also increased significantly $(8.6 \%)$ on day 7 , and on day $14(11.7 \%)$. The AUC (141.3 and $\left.148.8 \mu \mathrm{g} \mathrm{min} \mathrm{ml} \mathrm{m}^{-1}\right)$ and $C_{\max }(2.21$ and $2.30 \mathrm{ng} / \mathrm{ml})$ values were very similar on days 7 and 14 .

When levodopa and carbidopa were administered with $400 \mathrm{mg} / \mathrm{kg}$ of $P$. ovata husk, the increase in AUC values was slightly lower, although still significant. On day 7 , the AUC
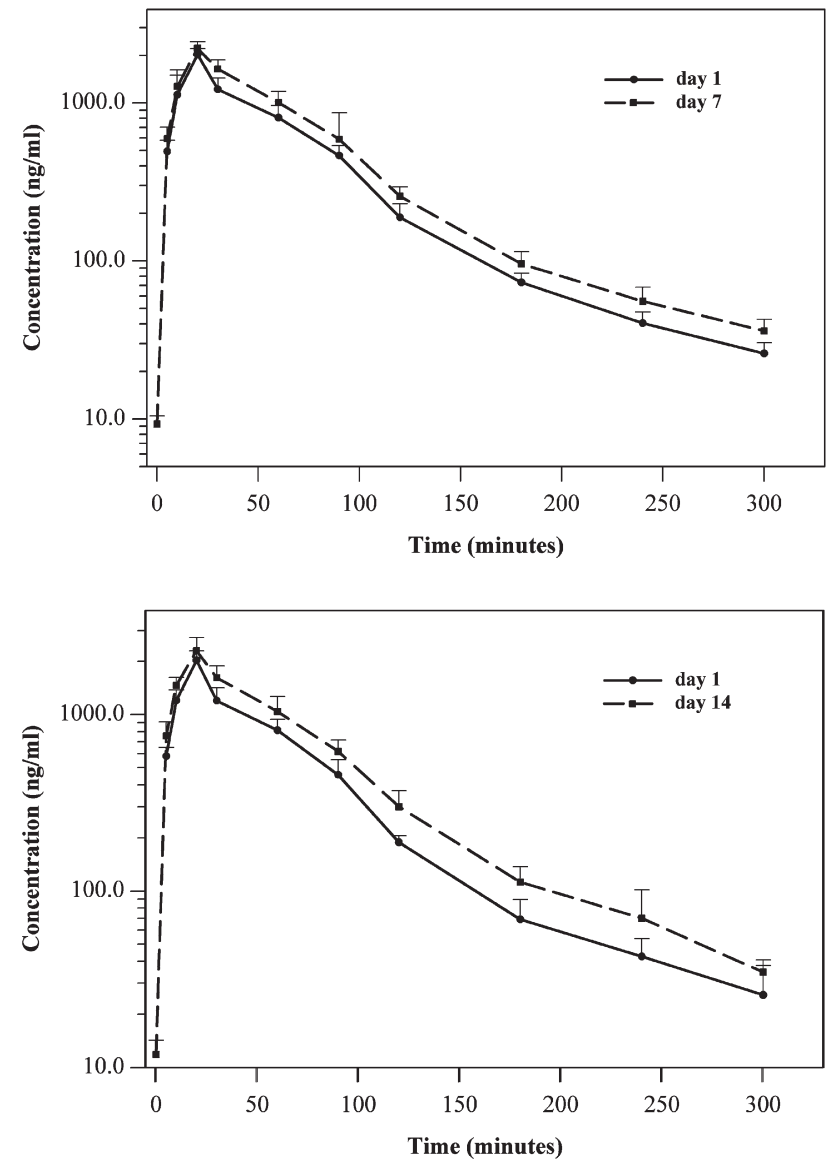

Fig. 1. Mean plasma concentrations of levodopa in rabbits after oral administration of 20:5 mg/kg levodopa/carbidopa and $100 \mathrm{mg} / \mathrm{kg}$ Plantago ovata husk for 7 and 14 days.

was $17.6 \%$ higher and on day 14 the AUC was $24.9 \%$ higher. The $C_{\max }$ increased $11.1 \%$ after 7 days of treatment and $11.3 \%$ after 14 days of treatment (significant differences). As observed with the $100 \mathrm{mg} / \mathrm{kg}$ dosage, the AUC values (159.2

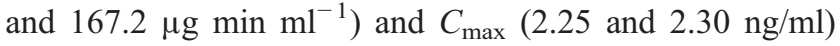
were very similar on days 7 and 14 .

If we evaluate the influence of the dose of fiber employed, we see that after 7 days of treatment, the AUC was higher (12.7\%) when administering $400 \mathrm{mg} / \mathrm{kg}$ fiber than when $100 \mathrm{mg} / \mathrm{kg}$ fiber was used (significant differences) while $C_{\max }$ was almost the same $(2.21$ and $2.25 \mathrm{ng} / \mathrm{ml})$. Similarly, on day 14 the AUC was also higher (12.4\%) in animals receiving the $400 \mathrm{mg} / \mathrm{kg}$ dose of fiber (significant differences), while the value of $C_{\max }$ was the same in both groups $(2.30 \mathrm{ng} / \mathrm{ml})$.

The levodopa concentrations at the different sampling times were always higher after 14 days of treatment, except at two points, where the values were slightly lower: $30 \mathrm{~min}$ (1634 vs $1615 \mathrm{ng} / \mathrm{ml})$ and $300 \mathrm{~min}(35.9$ vs $34.6 \mathrm{ng} / \mathrm{ml})$ after the administration of $100 \mathrm{mg} / \mathrm{kg}$ of fiber, and $10 \mathrm{~min}(1457$ vs $1417 \mathrm{ng} / \mathrm{ml})$ and $60 \mathrm{~min}(1075$ vs $1074 \mathrm{ng} / \mathrm{ml})$ after the administration of $400 \mathrm{mg} / \mathrm{kg}$ of fiber. 

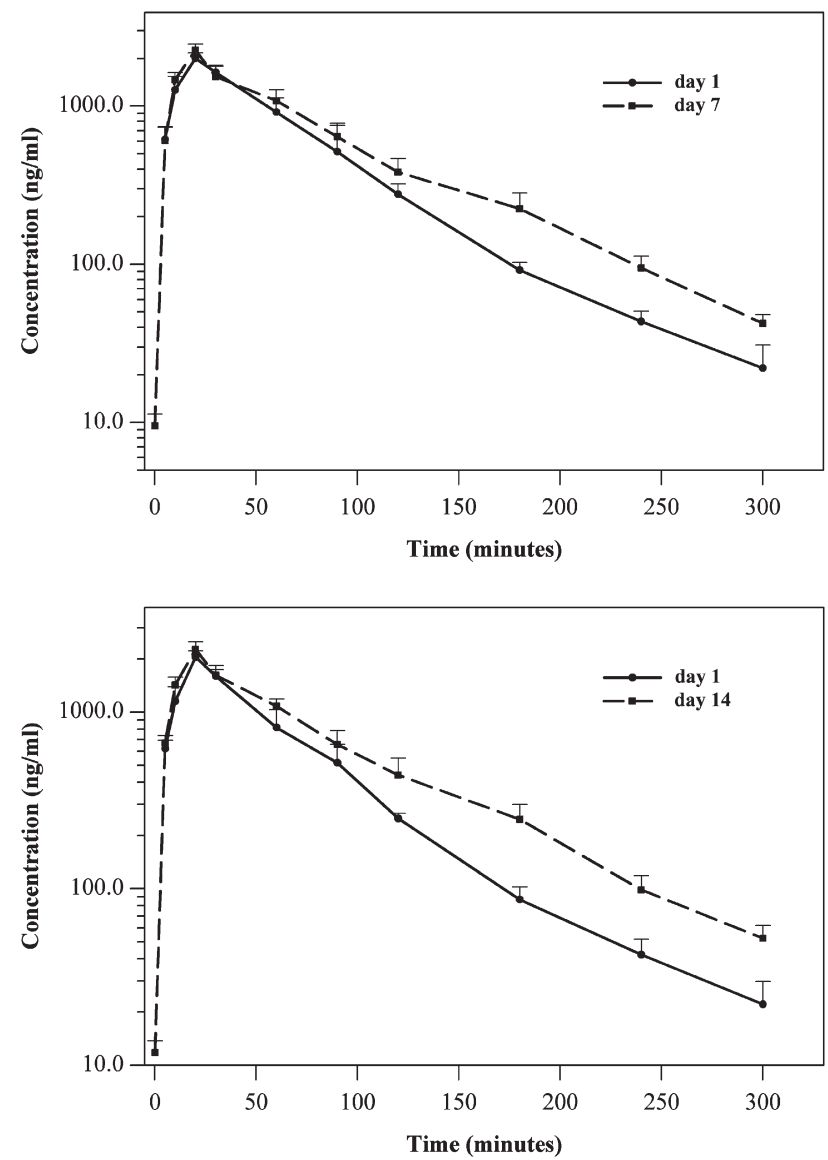

Fig. 2. Mean plasma concentrations of levodopa in rabbits after oral administration of $20: 5 \mathrm{mg} / \mathrm{kg}$ levodopa/carbidopa and $400 \mathrm{mg} / \mathrm{kg}$ Plantago ovata husk for 7 and 14 days.

The values obtained for $C_{\min }$ in the four groups increased progressively with the duration of treatment. $C_{\min }$ increased $19.2 \%$ from day 3 to day 7 after the administration of $100 \mathrm{mg} / \mathrm{kg}$
$P$. ovata husk, with significant increases occurring between day 3 and day 5, and between days 3, 5, and 7. After administration of $100 \mathrm{mg} / \mathrm{kg}$ fiber, $C_{\min }$ was $53.2 \%$ higher on day 14 than on day 3 , with significant differences between all data points except between days 11 and 14 . When the dose of fiber was $400 \mathrm{mg} / \mathrm{kg}, C_{\min }$ increased $17.3 \%$ from day 3 to day 7 , with significant increases occurring between day 3 and day 5, and between days 3, 5, and 7 . From day 3 to day 14, the increase in $C_{\min }$ was $28.4 \%$, with significant differences between all data points except between the values of days 9 and 11, and days 11 and 14 . If we compare both doses of fiber, the $C_{\min }$ values were almost the same on days 7 and 14 .

We observed that with a longer duration of treatment, there was an improvement in the extent of levodopa absorbed, resulting in higher final concentrations. These values were stabilized between days 7 and 9 of treatment. The time to reach the maximum plasma concentration $\left(t_{\max }\right)$ was $20 \mathrm{~min}$ in all groups.

For both doses of fiber, the MRT values increased significantly between days 1 and 7 , and days 1 and 14 . The highest MRT value obtained was on day 14 after the administration of $400 \mathrm{mg} / \mathrm{kg}$ of fiber $(83.2 \mathrm{~min})$. For both fiber doses, the $\mathrm{Cl}$ values decreased significantly between days 1 and 7, and days 1 and 14. There were no significant differences between pharmacokinetic parameters observed on days 7 and 14 .

\section{Discussion}

In this study we evaluated how the treatment dosage and duration of $P$. ovata husk modifies pharmacokinetic parameters of levodopa. The AUC values found on day 1 of treatment $\left(112.7,108.4,131.2\right.$ and $125.5 \mu \mathrm{g} \mathrm{min} \mathrm{ml}^{-1}$, respectively, in groups 1, 2, 3 and 4) are similar to those reported by Fernandez et al. [12] after administration of a single dose of

Table 1

Pharmacokinetic parameters obtained by non-compartmental analysis in rabbits after oral administration of 20:5 mg/kg levodopa/carbidopa and Plantago ovata husk $(100 \mathrm{mg} / \mathrm{kg})$ for 7 and 14 days

\begin{tabular}{|c|c|c|c|c|c|c|c|c|}
\hline \multirow[t]{2}{*}{ Parameters } & \multicolumn{2}{|l|}{ Day 1 of 7} & \multicolumn{2}{|l|}{ Day 7} & \multicolumn{2}{|l|}{ Day 1 of 14} & \multicolumn{2}{|l|}{ Day 14} \\
\hline & $\overline{\mathrm{x}} \pm \mathrm{SD}$ & $\mathrm{CV}(\%)$ & $\overline{\mathrm{x}} \pm \mathrm{SD}$ & $\mathrm{CV}(\%)$ & $\overline{\mathrm{X}} \pm \mathrm{SD}$ & $\mathrm{CV}(\%)$ & $\overline{\mathrm{x}} \pm \mathrm{SD}$ & $\mathrm{CV}(\%)$ \\
\hline$\lambda\left(\min ^{-1}\right)$ & $0.0085 \pm 0.0027$ & 31.52 & $0.0079 \pm 0.0016$ & 20.27 & $0.0105 \pm 0.0028$ & 26.41 & $0.0098 \pm 0.0023$ & 23.16 \\
\hline $\operatorname{AUC}\left(\mu \mathrm{g} \min \mathrm{ml}^{-1}\right)^{\mathrm{a}, \mathrm{d}}$ & $112.7 \pm 10.90$ & 9.68 & $141.3 \pm 18.22$ & 12.89 & $108.4 \pm 6.79$ & 6.27 & $148.8 \pm 23.23$ & 15.61 \\
\hline$C_{\max }\left(\mu \mathrm{g} \mathrm{ml}^{-1}\right)^{\mathrm{a}, \mathrm{c}}$ & $2.02 \pm 0.18$ & 9.15 & $2.21 \pm 0.23$ & 10.22 & $2.03 \pm 0.26$ & 13.06 & $2.30 \pm 0.43$ & 18.76 \\
\hline$t_{\max }(\min )$ & $20.0 \pm-$ & - & $20.0 \pm-$ & - & $20.0 \pm-$ & - & $20.0 \pm-$ & - \\
\hline $\mathrm{Cl} / \mathrm{F}\left(1 \mathrm{~kg}^{-1} \min ^{-1}\right)^{\mathrm{a}, \mathrm{c}}$ & $0.179 \pm 0.018$ & 9.85 & $0.144 \pm 0.019$ & 13.23 & $0.179 \pm 0.023$ & 12.63 & $0.137 \pm 0.020$ & 14.31 \\
\hline $\mathrm{V}_{\mathrm{a}} / \mathrm{F}\left(1 \mathrm{~kg}^{-1}\right)^{\mathrm{a}}$ & $22.9 \pm 6.96$ & 30.46 & $19.1 \pm 5.62$ & 29.46 & $20.3 \pm 6.31$ & 31.21 & $14.84 \pm 4.80$ & 32.32 \\
\hline $\mathrm{V}_{\mathrm{ss}} / \mathrm{F}\left(1 \mathrm{~kg}^{-1}\right)^{\mathrm{a}, \mathrm{c}}$ & $12.9 \pm 2.36$ & 18.34 & $10.7 \pm 1.63$ & 15.26 & $12.3 \pm 1.80$ & 14.85 & $9.87 \pm 1.46$ & 14.75 \\
\hline$t_{1 / 2 \lambda}(\min )$ & $87.2 \pm 21.1$ & 24.21 & $91.3 \pm 21.5$ & 23.49 & $71.1 \pm 22.5$ & 31.59 & $73.7 \pm 17.0$ & 23.03 \\
\hline $\operatorname{AUMC}\left(\mu \mathrm{g} \min ^{2} \mathrm{ml}^{-1}\right)^{\mathrm{b}, \mathrm{c}}$ & $8000 \pm 406$ & 5.07 & $10558 \pm 1807$ & 17.11 & $7389 \pm 1209$ & 16.36 & $10717 \pm 1691$ & 15.78 \\
\hline $\operatorname{MRT}(\min )^{a}$ & $71.5 \pm 6.86$ & 9.59 & $74.6 \pm 7.47$ & 10.02 & $67.9 \pm 3.74$ & 7.80 & $72.0 \pm 2.31$ & 3.21 \\
\hline F $(\%)$ & 96.4 & & 121.8 & & 92.7 & & 127.2 & \\
\hline
\end{tabular}

\footnotetext{
a Significant differences between day 1 and day 7 (t-test, $p \leq 0.05)$.

b Significant differences between day 1 and day 7 (Wilcoxon test, $p \leq 0.05$ ).

c Significant differences between day 1 and day 14 ( $t$-test, $p \leq 0.05$ ).

d Significant differences between day 1 and day 14 (Wilcoxon test, $p \leq 0.05$ ).
} 
Table 2

Pharmacokinetic parameters obtained by non-compartmental analysis in rabbits after oral administration of $20: 5 \mathrm{mg} / \mathrm{kg}$ levodopa/carbidopa and Plantago ovata husk (400 mg/kg) for 7 and 14 days

\begin{tabular}{|c|c|c|c|c|c|c|c|c|}
\hline \multirow[t]{2}{*}{ Parameters } & \multicolumn{2}{|l|}{ Day 1 of 7} & \multicolumn{2}{|l|}{ Day 7} & \multicolumn{2}{|l|}{ Day 1 of 14} & \multicolumn{2}{|l|}{ Day 14} \\
\hline & $\overline{\mathrm{x}} \pm \mathrm{SD}$ & CV $(\%)$ & $\overline{\mathrm{x}} \pm \mathrm{SD}$ & $\mathrm{CV}(\%)$ & $\overline{\mathrm{x}} \pm \mathrm{SD}$ & $\mathrm{CV}(\%)$ & $\overline{\mathrm{x}} \pm \mathrm{SD}$ & CV $(\%)$ \\
\hline$\lambda\left(\min ^{-1}\right)$ & $0.0118 \pm 0.0038$ & 31.90 & $0.0134 \pm 0.0021$ & 15.61 & $0.0115 \pm 0.0029$ & 25.41 & $0.0115 \pm 0.0011$ & 9.37 \\
\hline $\operatorname{AUC}\left(\mu \mathrm{g} \min \mathrm{ml}^{-1}\right)^{\mathrm{a}, \mathrm{b}}$ & $131.2 \pm 14.95$ & 11.39 & $159.2 \pm 18.57$ & 11.67 & $125.5 \pm 16.3$ & 13.03 & $167.2 \pm 11.51$ & 6.88 \\
\hline$C_{\max }\left(\mu \mathrm{g} \mathrm{ml}^{-1}\right)^{\mathrm{a}, \mathrm{b}}$ & $2.00 \pm 0.16$ & 8.14 & $2.25 \pm 0.20$ & 9.04 & $2.04 \pm 0.18$ & 8.72 & $2.30 \pm 0.43$ & 18.76 \\
\hline$t_{\max }(\min )$ & $20.0 \pm-$ & - & $20.0 \pm-$ & - & $20.0 \pm-$ & - & $20.0 \pm-$ & - \\
\hline $\mathrm{Cl} / \mathrm{F}\left(1 \mathrm{~kg}^{-1} \min ^{-1}\right)^{\mathrm{a}, \mathrm{b}}$ & $0.154 \pm 0.017$ & 10.96 & $0.127 \pm 0.016$ & 12.83 & $0.162 \pm 0.020$ & 12.05 & $0.120 \pm 0.008$ & 6.78 \\
\hline $\mathrm{V}_{\mathrm{a}} / \mathrm{F}\left(1 \mathrm{~kg}^{-1}\right)$ & $14.4 \pm 6.13$ & 42.51 & $9.71 \pm 1.71$ & 17.66 & $15.0 \pm 4.64$ & 31.03 & $10.51 \pm 0.98$ & 9.36 \\
\hline $\mathrm{V}_{\mathrm{ss}} / \mathrm{F}\left(1 \mathrm{~kg}^{-1}\right)^{\mathrm{a}}$ & $10.3 \pm 1.73$ & 16.74 & $10.0 \pm 1.29$ & 12.84 & $10.7 \pm 1.68$ & 15.70 & $9.97 \pm 0.53$ & 5.31 \\
\hline$t_{1 / 2 \lambda}(\min )$ & $64.6 \pm 23.0$ & 35.66 & $53.0 \pm 8.64$ & 16.29 & $63.5 \pm 15.9$ & 25.12 & $60.8 \pm 5.84$ & 9.61 \\
\hline $\operatorname{AUMC}\left(\mu \mathrm{g} \min ^{2} \mathrm{ml}^{-1}\right)^{\mathrm{a}, \mathrm{b}}$ & $8753 \pm 1063$ & 12.14 & $12585 \pm 1807$ & 14.36 & $8252 \pm 963$ & 11.66 & $13942 \pm 1646$ & 11.81 \\
\hline MRT (min) & $66.9 \pm 6.45$ & 9.64 & $78.9 \pm 4.13$ & 5.23 & $66.0 \pm 4.67$ & 7.08 & $83.2 \pm 4.86$ & 5.85 \\
\hline $\mathrm{F}(\%)$ & 112.2 & & 136.1 & & 107.3 & & 143.0 & \\
\hline
\end{tabular}

${ }^{a}$ Significant differences between day 1 and day 7 ( $t$-test, $\left.p \leq 0.05\right)$.

b Significant differences between day 1 and day 14 ( $t$-test, $p \leq 0.05$ ).

levodopa/carbidopa and fiber to rabbits $(109$ and $129 \mu \mathrm{g}$ min $\mathrm{ml}^{-1}$, respectively, with 100 and $400 \mathrm{mg} / \mathrm{kg}$ of fiber). The values reported by these authors for $C_{\max }(1.97$ and $2.07 \mu \mathrm{g}$ $\mathrm{ml}^{-1}$, with 100 and $400 \mathrm{mg} / \mathrm{kg}$ of fiber, respectively) were also similar to those obtained in this study $(2.02,2.03,2.00$ and $2.04 \mu \mathrm{g} \mathrm{ml}^{-1}$, respectively, in groups 1, 2, 3 and 4).

We carried out another study administering $20: 5 \mathrm{mg} / \mathrm{kg}$ levodopa/carbidopa for 7 and 14 days without fiber [14]. Comparing the results of this study with those of the present one we observe that after the administration of $100 \mathrm{mg} / \mathrm{kg}$ of P. ovata husk, the value of AUC was lower (17.9\%) on day 1, and also on days 7 and 14, although this decrease was lower (6.2\% and $5.5 \%$, respectively). With the administration of $400 \mathrm{mg} / \mathrm{kg}$ of fiber, the AUC values were similar to those obtained without fiber, decreasing slightly on day $1(4.7 \%)$ and increasing slightly on days 7 and $14(5.8 \%$ and $6.3 \%$, respectively). These results indicate that the duration of drug administration, as well as the dosage of fiber, affects levodopa absorption. The values of $C_{\max }$ were always lower after administering $P$. ovata husk, by nearly $18 \%$ in all treatments, if we compare the data obtained with those reported by Fernandez et al. [14].

In a previous study [12] in which a single dose of these drugs was given to rabbits, it was demonstrated that the AUC values diminished in the presence of $P$. ovata husk: $29.7 \%$ after the administration of $100 \mathrm{mg} / \mathrm{kg}$ fiber, and $20.4 \%$ with $400 \mathrm{mg} / \mathrm{kg}$ fiber. However, these decreases were larger than those found in the present study. This previous study also

Table 3

Values of $C_{\min }$ and $C_{\max }(\mu \mathrm{g} / \mathrm{ml})$ obtained after oral administration of $20: 5 \mathrm{mg} / \mathrm{kg}$ levodopa/carbidopa and Plantago ovata husk (100 or $400 \mathrm{mg} / \mathrm{kg}$ ) for $7 \mathrm{and}$ 14 days to rabbits

\begin{tabular}{|c|c|c|c|c|c|}
\hline & & \multicolumn{2}{|l|}{$100 \mathrm{mg} / \mathrm{kg}$} & \multicolumn{2}{|l|}{$400 \mathrm{mg} / \mathrm{kg}$} \\
\hline & & $\overline{\mathrm{x}} \pm \mathrm{SD}$ & CV (\%) & $\overline{\mathrm{x}} \pm \mathrm{SD}$ & CV (\%) \\
\hline \multirow[t]{3}{*}{$C_{\min }(0 \min )$} & Day 3 & $0.0078 \pm 0.0012$ & 15.07 & $0.0081 \pm 0.0015$ & 18.82 \\
\hline & Day 5 & $0.0084 \pm 0.0013^{\mathrm{b}}$ & 16.05 & $0.0088 \pm 0.0016^{\mathrm{b}}$ & 17.70 \\
\hline & Day 7 & $0.0093 \pm 0.0012^{\mathrm{b}, \mathrm{c}}$ & 12.66 & $0.0095 \pm 0.0017^{\mathrm{b}, \mathrm{c}}$ & 18.45 \\
\hline \multirow[t]{4}{*}{$C_{\max }(20 \mathrm{~min})$} & Day 1 & $2.02 \pm 0.18$ & 9.15 & $2.00 \pm 0.16$ & 8.14 \\
\hline & Day 3 & $2.08 \pm 0.18$ & 8.78 & $2.09 \pm 0.21^{\mathrm{a}}$ & 9.94 \\
\hline & Day 5 & $2.11 \pm 0.19^{\mathrm{a}}$ & 8.98 & $2.24 \pm 0.23^{\mathrm{a}, \mathrm{b}}$ & 10.12 \\
\hline & Day 7 & $2.21 \pm 0.23^{\mathrm{a}, \mathrm{b}, \mathrm{c}}$ & 10.22 & $2.25 \pm 0.20^{\mathrm{a}, \mathrm{b}}$ & 9.04 \\
\hline \multirow{5}{*}{$C_{\min }(0 \min )$} & Day 3 & $0.0077 \pm 0.0020$ & 26.21 & $0.0092 \pm 0.0017$ & 18.04 \\
\hline & Day 6 & $0.0086 \pm 0.0016^{\mathrm{e}}$ & 18.96 & $0.0097 \pm 0.0021$ & 21.95 \\
\hline & Day 9 & $0.0096 \pm 0.0017^{\mathrm{e}, \mathrm{f}}$ & 17.74 & $0.0105 \pm 0.0023^{\mathrm{e}, \mathrm{f}}$ & 21.33 \\
\hline & Day 11 & $0.0112 \pm 0.0024^{\mathrm{e}, \mathrm{f}, \mathrm{g}}$ & 21.48 & $0.0111 \pm 0.0018^{\mathrm{e}, \mathrm{f}}$ & 16.06 \\
\hline & Day 14 & $0.0118 \pm 0.0024^{\mathrm{e}, \mathrm{f}, \mathrm{g}}$ & 20.61 & $0.0117 \pm 0.0020^{\mathrm{e}, \mathrm{f}, \mathrm{g}}$ & 16.94 \\
\hline \multirow[t]{6}{*}{$C_{\max }(20 \min )$} & Day 1 & $2.03 \pm 0.26$ & 13.06 & $2.04 \pm 0.18$ & 8.72 \\
\hline & Day 3 & $2.16 \pm 0.44$ & 20.51 & $2.04 \pm 0.18$ & 8.72 \\
\hline & Day 6 & $2.22 \pm 0.48$ & 21.87 & $2.06 \pm 0.21$ & 10.38 \\
\hline & Day 9 & $2.27 \pm 0.53$ & 23.39 & $2.13 \pm 0.21$ & 10.03 \\
\hline & Day 11 & $2.40 \pm 0.66^{\mathrm{d}}$ & 27.40 & $2.21 \pm 0.21^{\mathrm{d}, \mathrm{e}, \mathrm{f}}$ & 9.68 \\
\hline & Day 14 & $2.30 \pm 0.43^{\mathrm{d}}$ & 18.76 & $2.26 \pm 0.23^{\mathrm{d}, \mathrm{e}, \mathrm{f}, \mathrm{g}}$ & 10.02 \\
\hline
\end{tabular}

Significant differences: ${ }^{\mathrm{a}}$ with day $1 ;{ }^{\mathrm{b}}$ with day $3 ;{ }^{\mathrm{c}}$ with day 5 (Duncan test, $p \leq 0.05$ ).

Significant differences: ${ }^{\mathrm{d}}$ with day $1 ;{ }^{\mathrm{e}}$ with day $3 ;{ }^{\mathrm{f}}$ with day $6 ;{ }^{\mathrm{g}}$ with day 9 ; (Duncan test, $p \leq 0.05$ ). 
had larger decreases in $C_{\max }$ with both doses of fiber: $28.1 \%$ with $100 \mathrm{mg} / \mathrm{kg}$ fiber, and $24.6 \%$ with $400 \mathrm{mg} / \mathrm{kg}$ [12].

The final plasma concentrations are always higher in the presence of $P$. ovata husk, with the greatest concentrations occurring after administration of $400 \mathrm{mg} / \mathrm{kg}$ fiber. This was also described by Fernandez et al. [12].

When comparing the values we obtained for MRT and $\mathrm{Cl} / \mathrm{F}$ with those obtained without administration of fiber [14], it is clear that the values of $\mathrm{Cl} / \mathrm{F}$ and MRT are always higher after the administration of $100 \mathrm{mg} / \mathrm{kg} \mathrm{P}$. ovata husk. However, when the fiber dose employed is $400 \mathrm{mg} / \mathrm{kg}, \mathrm{Cl} / \mathrm{F}$ values are very similar and MRT values are higher in the presence of fiber.

Our findings support the conclusions stated in previous works $[11,12]$, in which it was found that fiber administration could reduce the severity of dopamine-mediated gastrointestinal and cardiovascular adverse effects by providing lower levodopa maximum concentrations. Fiber can also improve "on-off" and "wearing-off" situations due to an increase in the half-life and final concentration of levodopa, with less fluctuations in plasma concentrations. These findings are very important for the optimization of levodopa pharmacokinetics $[6,15]$. After years of treatment with levodopa, at least $50 \%$ of Parkinson's patients develop fluctuations in motor performance. The "wearing-off" effect occurs in $10 \%$ of levodopatreated patients. Unpredictable and severe "on-off" swings eventually appear in $10-15 \%$ of patients after 5 or more years of treatment. Although the pathophysiological mechanisms underlying these episodes are poorly understood, they frequently correspond to decreases in levodopa plasma levels [1].

The results of this study reaffirm the idea that $P$. ovata husk can partially inhibit LAAD activity, as has been described with other enzymes [16-18]. In addition, fiber could retain some of the levodopa to make it available for absorption in more distal portions of the intestine, which would explain the final higher plasma levodopa concentrations that are observed when fiber is administered.

Taking into account the results obtained: improvement of levodopa kinetic profile with higher final concentrations, a longer plasma half-life and lower $C_{\max }$, we think that $P$. ovata husk offers interesting perspectives to be administered to patients with Parkinson disease, although further clinical studies are necessary.

\section{Acknowledgement}

We wish to thank Madaus, S.A. Laboratory for its collaboration in this study.

\section{References}

[1] Shoulson I, Glaubiger GA, Chase TN. On-off response. Clinical and biochemical correlations during oral and intravenous levodopa administration in parkinsonian patients. Neurology 1975;25:1144-8.

[2] Kempster PA, Frankel JP, Bovingdon M, Webster R, Lees AJ, Stern GM. Levodopa peripheral pharmacokinetics and duration of motor response in Parkinson's disease. J Neurol Neurosurg Psychiatr 1989;52:718-23.

[3] Bredberg E, Tedroff J, Aquilonius SM, Paalzow L. Pharmacokinetics and effects of levodopa in advanced Parkinson's disease. Eur J Clin Pharmacol 1990;39:385-9.

[4] Deleu D, Sarre S, Ebinger G, Michotte Y. In vivo pharmacokinetics of levodopa and 3-O-methyldopa in muscle. A microdialysis study. Naunyn-Schmiedebergs Arch Pharmacol 1991;344:514-9.

[5] Castro A, Valldeoriola F, Linazasoro G, Rodríguez-Oroz MC, Stochi F, Marin C, et al. Optimizacion del uso de la levodopa en la enfermedad de Parkinson: papel de la combinacion levodopa-carbidopa-entacapona. Neurologia 2005;20:180-8.

[6] Olanow CW, Obeso JA, Stocchi F. Continuous dopamine-receptor treatment of Parkinson's disease: scientific rationale and clinical implications. Lancet Neurol 2006;5:677-87.

[7] Rivera-Calimlim L, Dujovne CA, Morgan JP, Lasagna L, Bianchine JR. L-dopa treatment failure: explanation and correction. $\mathrm{Br}$ Med J 1970;10:93-4.

[8] Nutt JG, Woodward WR, Hammerstad JP, Carter JH, Anderson JL. The "on-off" phenomenon in Parkinson's disease. Relation to levodopa absorption and transport. New Engl J Med 1984;310:483-8.

[9] Van Laar T. Levodopa-induced response fluctuations in patients with Parkinson's disease: strategies for management. CNS Drugs 2003;17:475-89.

[10] Özge A, Bugdayci R, Togrol E, Saracoglu M. The relation of gastrointestinal symptoms to duration of levo-dopa treatment and severity of Parkinson's Disease. J Appl Res 2003;3:349-55.

[11] Garcia JJ, Fernandez N, Carriedo D, Diez MJ, Sahagun A, Gonzalez A, et al. Hydrosoluble fiber (Plantago ovata husk) and levodopa I: experimental study of the pharmacokinetic interaction. Eur Neuropsychopharmacol 2005; 15:497-503.

[12] Fernandez N, Carriedo D, Sierra M, Diez MJ, Sahagun A, Calle A, et al. Hydrosoluble fiber (Plantago ovata husk) and levodopa II: experimental study of the pharmacokinetic interaction in the presence of carbidopa. Eur Neuropsychopharmacol 2005;15:505-9.

[13] Gibaldi M, Perrier D. Multicompartment models in Pharmacokinetics. 2nd ed. New York: Marcel Dekker; 1982. p. 45-111.

[14] Fernandez N, Prieto C, Sierra M, Diez MJ, Sahagun A, Gonzalez A, et al. Evolution of the bioavailability and other pharmacokinetic parameters of levodopa (with carbidopa) in rabbits. Meth Find Exp Pharmacol 2008;30:1-7.

[15] Lim E. A wall through the management of Parkinson's disease. Ann Acad Med Singap 2005;34:188-95.

[16] Isaksson G, Lundquist I, Ihse I. Effect of dietary fiber on pancreatic enzyme activity in vitro. Gastroenterology 1982;82:918-24.

[17] Hansen WE. Effect of dietary fiber on proteolytic pancreatic enzymes in vitro. Int J Pancreatol 1986;1:341-51.

[18] Leng-Peschlow E. Interference of dietary fibres with gastrointestinal enzymes in vitro. Digestion 1989;44:200-10. 